\title{
Phytochemical and antibacterial properties of sea cucumber (Muelleria lecanora) from Barrang Lompo Islands, Makassar South Sulawesi
}

\author{
${ }^{1 *}$ Yusuf, M., ${ }^{2}$ Fitriani Nur, U.A., ${ }^{1}$ Mahyati, L. and ${ }^{2}$ Imran, M. \\ ${ }^{1}$ Department of Chemical Engineering, Politeknik Negeri Ujung Pandang, Jl. Perintis Kemerdekaan KM. 10 \\ Tamalanrea, 90245, Makassar City, Indonesia \\ ${ }^{2}$ Department of Agroindustry, Politeknik Pertanian Negeri Pangkep, Jl. Poros Makassar - Parepare KM. 83 \\ Mandalle, 90655, Pangkep Regency, Indonesia
}

\author{
Article history: \\ Received: 22 April 2020 \\ Received in revised form: 29 \\ May 2020 \\ Accepted: 8 June 2020 \\ Available Online: 22 July \\ 2020
}

Keywords:

Antibacterial,

Phytochemicals,

Sea cucumber,

Maceration extraction

DOI:

https://doi.org/10.26656/fr.2017.4(6).187

\begin{abstract}
Barrang Lompo Island Waters is home for different species of marine biota of sea cucumber (Muelleria lecanora). Many sea cucumber species have been used as health supplements because they contain bioactive compounds that are beneficial to people in Indonesia. Given this, our study was designed to investigate the phytochemical, and antibacterial properties of crude acetone, methanol and hexane extract of sea cucumber using maceration extraction methods. The sea cucumber extract was prepared and the phytochemical profile was studied by analysing Gas Chromatography-Mass Spectrometry (GC-MS). Results showed that the extracts were a complex mixture of numerous compounds; many of which were present in trace amounts antioxidants and antimicrobial; hexadecanoic acid, methyl ester, 9-octadecenoic acid (z) -, methyl ester (stearic acid methyl ester), octadecanoic acid, methyl ester, 2-[(hexadecyloxy)methyl]oxirane, cholest5-en-3-yl acetate, ergosta-14,22-dien-3-ol, acetate,(3.beta.,5.alpha.,22e), 5,8,11,14eicosatetraenoic acid, methyl ester, (all-z) epa/omega 3, pentacosane, hexatriacontane, and 9-hexadecenoic acid, methyl ester, (Z). The extract was also evaluated for activity against three pathogenic bacterial strains (Escherichia coli, Staphylococcus aureus and Salmonella) using the disc diffusion method. The extract exhibited clear zones of inhibition against the tested bacteria. Maximum inhibitory zone concentration values were demonstrated to be: Escherichia coli $=6.84 \mathrm{~mm}$, Staphylococcus aureus $=7.22 \mathrm{~mm}$, and Salmonella $=7.87 \mathrm{~mm}$. These results revealed the significant potential of sea cucumber as a source of antioxidants and antimicrobial agents and also highlight the necessity of further purification and characterisation of solitary bioactive compounds for their prospective applications in pharmaceutical industries, food, and nutraceutical (food functional).
\end{abstract}

\section{Introduction}

The increasing number of scientific research and journals published in recent decades has to do with functional materials derived from vegetable and animal natural resources, potentially as food functional, nutraceuticals and health supplement products that support nutritional value needs and improve body health. Among other marine animals, sea cucumber is a source of natural ingredients that contain functional ingredients and bioactive compound that can be used in biomedicine and food processing industries. Sea cucumber is a marine invertebrate of the Holothuroidea class, has rough skin on its outer and elongated body and contains a single branched gonad. This marine animal has a wide number of species, ranging from 1716 species, with the largest potential of biological diversity in the Asia-Pacific region. In Indonesia, it is known as "Teripang or Trepang", in France under the name "Beche-De-Mer", which means seafood products, and "Balate" in the islands of Guam or Chomorro. Sea cucumber includes living marine animals with complex environments, making it difficult to live in extreme environments, therefore the sea cucumber can produce biologically active secondary metabolites that can not be found and obtained from other marine animals (Pangestuti and Arifin, 2018).

The sea cucumber has a complete nutritional content, low-fat content, high protein, and rich essential amino 
acids, such as tryptophan, arginine, and lysine, as well as having a body wall consisting of non-soluble collagen which can be used as a nutritional supplement (Chen, 2004). Sea cucumber has been recognized as a traditional remedy for treating asthma, rheumatism, hypertension, impotence, constipation and burns (Wen et al., 2010). Other functions, among others, anti-coagulant (Nagase et al., 1995; Chen et al., 2011), anticancer (Janakiram et al., 2015), anti-inflammatory (Olivera-Castillo et al., 2018), antithrombotic (Mourão et al., 1998; Pacheco et al., 2000), antioxidant (Althunibat et al., 2009), antimicrobial (Beauregard et al., 2001; Hing et al., 2007), antihypertensive (Zhao et al., 2007), antiangiogenic (Roginsky et al., 2004; Tian et al., 2005), antitumor (Zou et al., 2003; Tong et al., 2005), and healing wound (San Miguel-Ruiz and García-Arrarás, 2007), due to the role of bioactive compounds present in the sea cucumber mainly the triterpene glycosides (saponin) (Miyamoto et al., 1990; Kerr and Chen, 1995; Aminin et al., 2010), phenolics (Mamelona et al., 2007), lectins (Mojica and Merca, 2004, 2005), sterols (glycosides and sulfate) (Han et al., 2009), peptides (Zhou et al., 2012), glycosaminoglycan (Kariya et al., 1990; Borsig et al., 2007), chondroitin sulfate (Ustyuzhanina et al., 2016), cerebrosides (Sugawara et al., 2006), and sulfate polysaccharides (Luo et al., 2013). This bioactive compound can be used as a potential antibacterial. Antibacterial is a compound that can suppress the growth and development of bacteria, the ability of bioactive compounds in the sea, which makes researchers interested in researching a sea cucumber. The need to find new antimicrobial material is increasing, because the growth and development of bacteria are currently able to be resistant to antibiotics, as well as the growing conventional antibiotics (Li et al., 2008).

Nguyen et al. (2011) reported about potent $\alpha-$ Glucosidase inhibitory activity purified from the body wall of Sea Cucumber (Stichopus japonicus). The result shows that sea cucumber fatty acids can potentially be developed as a novel natural nutraceutical for the management of type - 2 diabetes. Other research, indicating that sea cucumber Apostichopus japonicus, analysis in vitro show inhibitory zones on microbes strains Vibrio splendidus, Vibrio harveyi and Staphylococcus aureus (Jiang et al., 2014). The antibacterial activity of sea cucumber Actinopyga lecanora against some common pathogenic Grampositive bacteria (Bacillus subtilis and Staphylococcus aureus) and Gram-negative bacteria (Escherichia coli, Pseudomonas aeruginosa, and Pseudomonas spp.), was evaluated. It was indicated that sea cucumber extract was able to inhibit Staphylococcus aureus (Ghanbari et al., 2012). Five curvularin macrolides in isolation from sea cucumber Holothuria moebii, results in 11- hydroxycurvularins $\quad((11 S, 15 R)-11$-hydroxycurvularin) and $((11 R, 15 R)-11$-hydroxycurvularin) also showed antibacterial activity inhibiting the growth of Escherichia coli (Ye et al., 2016). Previous studies on antibacterial activity of sea cucumber extracts have been reported against several pathogenic bacteria such as Escherichia coli, Salmonella, Listeria, and Staphylococcus aureus. Previous literature showed that sea cucumber is extensively studied for antioxidant and antimicrobial activities.

In this study, sea cucumber is used for investigating antioxidant and antimicrobial potential using maceration extraction with three solvents (acetone, hexane and methanol). The present work aimed to investigate the efficiency of different solvents for the phytochemical extraction from sea cucumber and to identify and analyze the bioactive compounds by GC-MS (Gas Chromatography-Mass Spectrometry). The antibacterial efficacy against pathogenic bacteria Escherichia coli, Salmonella and Staphylococcus aureus using disc diffusion methods was also investigated.

\section{Materials and methods}

\subsection{Materials}

Sea cucumber phylum Echinodermata, family Holothuriidae and genus Muelleria lecanora (Figure 1) collected from the coast Barrang Lompo Island in Makassar, South Sulawesi, Indonesia. During the trip, sea cucumber is stored in a cooling box that contains an ice pack and is moved into the freezer after arriving in the laboratory and processed in Food Science and Instrumental Analysis Laboratory, Chemical Engineering Department, Politeknik Negeri Ujung Pandang, Indonesia.
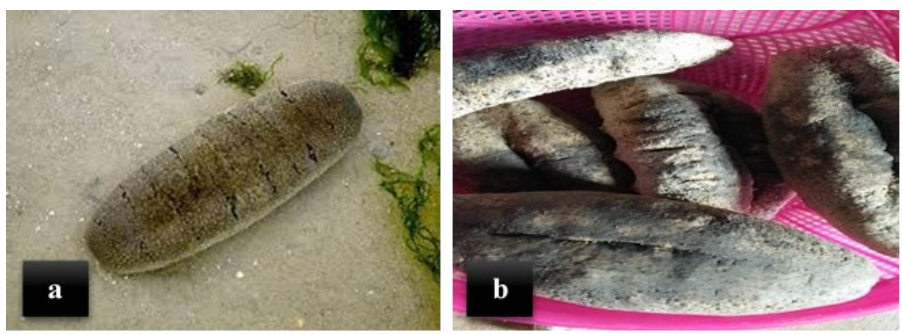

Figure 1. Sea cucumber (Muellaria lecanora): a) freshwater and b) dried.

All chemicals were of analytical grade, hexane (CAS: 110-54-3), methanol (CAS: 67-56-1), acetone (CAS: 67-64-1), nutrient agar (CAS:105450), aquadestilata (CAS: 7732-18-5), plate count agar (CAS: 105463), McFarland Standard (barium chloride and sulfuric acid), sodium chloride (CAS: 7647-14-5), pH paper, disc antibiotic blank (Whatman No.1 and No. 5), dimethyl sulfoxide (CAS: 67-68-5) supplied by Merck Millipore (Burlington, Massachusetts, United States), 
Tetracycline hydrochloride (CAS: 64-75-5) supplied by Sigma Aldrich (St. Louis, Missouri, United States), culture strains Staphylococcus aureus, Salmonella and Escherichia coli.

\subsection{Preparation of extracts}

The sea cucumbers were cleaned and dried in an oven at $70^{\circ} \mathrm{C}$, then cropped small-minced. About $100 \mathrm{~g}$ of the sea cucumbers were homogenized and extracted using the maceration method with a ratio of volume 1:2 (V/V) methanol, acetone or n-hexane. Samples were allowed for $72 \mathrm{hrs}$ with solvent replacement every $24 \mathrm{hrs}$ and were stirring with orbital shakers. The resulting extraction (macerate) is then filtered and concentrated with a rotary evaporator at $40^{\circ} \mathrm{C}$ until the extract is obtained. The Supernatant is produced for each sample, then in centrifugation for 10 mins and stored at a temperature of $10^{\circ} \mathrm{C}$, for use in analysis bioactive compound in GC-MS and antibacterial disc diffusion method.

\subsection{Gas Chromatography-Mass Spectrometry(GC-MS)}

Sea cucumber was analyzed using GC-MS using capillary column DB-5 $(30 \mu \mathrm{m}, 0.25 \mathrm{~mm}, 0.25 \mu \mathrm{m}$ film $)$ and Flame Ionization Detector (FID) operated in EI mode at $70 \mathrm{eV} .1 \mathrm{~mL}$ of the sea cucumber was added with $3 \mathrm{~mL}$ of methanol $96 \%$ in the reaction tube and vortex. The injectors and detector temperature are set at $220^{\circ} \mathrm{C}$ and $250^{\circ} \mathrm{C}$. A sample was dissolved with $1 \mu \mathrm{l}$ methanol, then injected and analyzed at $60^{\circ} \mathrm{C}$ for 2 minutes and then increased $3^{\circ} \mathrm{C} / \mathrm{min}$ to $300^{\circ} \mathrm{C}$, with Helium $(\mathrm{He})$ is used as carrier gas $(1 \mathrm{~mL} / \mathrm{min})$. This analysis will generate two GC data in the form of chromatogram which displays the peaks of the compound contained in the methanol, acetone or nhexane extract and the current MS (Mass Spectroscopy) data shows the molecular weight at each peak. Any peaks appearing on the GC chromatogram indicate a single molecule and have a fragmentation pattern displayed in the MS spectra. Based on the fragmentation pattern can be identified what compounds are contained in the sea cucumber sample.

\subsection{Test microorganisms and culture media}

Test microorganisms Salmonella, Staphylococcus aureus and Escherichia coli used in this study were obtained from the Microbiology Laboratory, Department of Biology, State University of Makassar. The bacteria was grown at $32^{\circ} \mathrm{C}$ in nutrient broth (DIFCO Laboratories, Detroit, USA) following standard procedures (Keagle and Gersen, 2005).

\subsection{Antimicrobial assay}

Disc antibiotic blank (Whatman No. 1) was cut to size and sterilized with other equipment using autoclaved at $121^{\circ} \mathrm{C}$ for 15 mins. Growth media microorganisms are $5 \mathrm{~g}$ nutrient agar (NA), dissolved $250 \mathrm{~mL}$ of aquadest in the Erlenmeyer $500 \mathrm{~mL}$, then heated to homogeneous. The sodium chloride solvent was obtained by $0.9 \mathrm{~g}$ $\mathrm{NaCl}$, then dissolved in a $100 \mathrm{~mL}$ volumetric flask, and inserted into the reaction tube $9 \mathrm{~mL}$. Mc Farland solvent obtained, by mixing a solution of barium chloride $\left(\mathrm{BaCl}_{2}\right) 1.175 \%$ and a solution of sulphuric acid $\left(\mathrm{H}_{2} \mathrm{SO}_{4}\right)$ $1 \%$, so that the solvent obtained Mc Farland $0.5 \%$ to be used as standard turbidity (absorbance $600 \mathrm{~nm}$ ). Media nutrient agar, and sodium chloride solvent was sterilized using autoclave at temperature $121^{\circ} \mathrm{C}$ for 15 mins.

Sterile nutrient agar $20 \mathrm{~mL}$ was poured in Petri dishes, allowed to set at $37^{\circ} \mathrm{C}$ and then inoculate uniformly with $0.1 \mathrm{~mL}$ of a $24 \mathrm{hr}$ broth culture of test bacteria (Abubakar et al., 2012). Sea cucumber extract $(0.25 \mathrm{~g})$ were dissolved in $1 \mathrm{~mL}$ aqueous dimethylsulfoxide (DMSO) with tween $80(0.5 \% \mathrm{v} / \mathrm{v}$ for easy diffusion) and sterilized by filtration through a 0.45 $\mu \mathrm{m}$ membrane filter. Under aseptic condition, each sterile disc (Whatman no. 5, $6 \mathrm{~mm}$ dia) was then dipped in $20 \mu \mathrm{L}$ of the extracts and carefully placed on the agar plate using flame sterilized forceps, ensuring the discs were at least $2 \mathrm{~cm}$ separate from one another. After 30 mins, plates were inverted and incubated at $37^{\circ} \mathrm{C}$ for 48 $\mathrm{hr}$, followed by measuring the inhibitory zone for each sample and the type of bacteria in $\mathrm{mm}$. An experiment was carried out in duplicate and the averages diameter of zone of inhibition was recorded. Negative controls use a $10 \%$ DMSO solvent, and one paper disc is given a tetracycline of $\mathrm{HCl}$ as a positive control, antibacterial activity was classified as highly active $(>10 \mathrm{~mm})$, mild active $(7-10 \mathrm{~mm})$ and slightly active $(6-7 \mathrm{~mm})$ and less than $6 \mathrm{~mm}$ was taken as inactive (Chandra et al., 2011).

\section{Results and discussion}

3.1. Yield analysis extract of methanol, acetone and hexane

The effect of extraction time on the yield of sea cucumber obtained using various solvents (methanol, acetone and hexane) is shown in Figure 2. The solvent used is the polar methanol, acetone is semi-polar and the hexane is non-polar. The highest yield of $18.96 \%$ by using a methanol solvent, while the lowest yield of $0.14 \%$ using hexane solvent was obtained. Acetone solvent obtained a yield of $8.19 \%$. This suggests that the ability of methanol solvent in extracting a compound is very good compared to other solvents. 


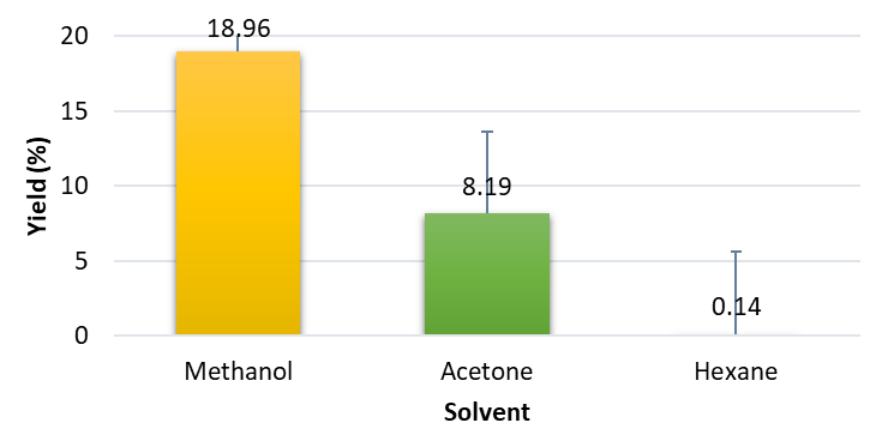

Figure 2. Effect of different solvents to sea cucumber extract yield value.

\subsection{GC-MS analysis}

The presence of a bioactive compound in the methanol, acetone, and hexane extract of sea cucumber was characterized by GC-MS analysis (Table 1).

The spectrum of GC -MS for acetone, hexane and methanol extract of sea cucumber for 39 mins are shown in Figure 3, 4 and 5. GC-MS result analysis includes the active principles with their, molecular formula, amount of component and composition in the methanol extracts of sea cucumber. List of the identified compounds in the extract and percentage composition is shown in Table 1 . Results showed that the extracts were a complex mixture of numerous compounds; many of which were present in trace amounts antioxidants and antimicrobial. Cholest-5EN-3-YL Acetate (12,6\%), Hexadecanoic Acid, Methyl Ester $(10.32 \%)$, Octadecanoic acid, methyl ester (8,49\%), Ergosta-14,22-Dien-3-OL,Acetate, (3.Beta.,5.Alpha.,22E)- (8.18\%), Stigmast-5-EN-3-OL, (3.Beta.,24S)-/gamma.-Sitosterol (7.56\%), 9Hexadecenoic acid, methyl ester, (Z) (5.19\%), 9Octadecenoic acid (Z) -, methyl ester (stearic acid methyl ester) (4.11\%), 2-[(Hexadecyloxy)Methyl] Oxirane (3.36\%\%), and,5,8,11,14-Eicosatetraenoic Acid, Methyl Ester, (ALL-Z) EPA/Omega 3 (2.37\%), plays a vital role for antibacterial and antioxidant activities. Steroid and flavonoid is the major component in sea cucumber and had good agreement with the results by Silchenko et al. (2008) sea cucumbers are rich in glycosides, particularly triterpene glycosides which are proven to have antifungal and antitumor activities (Han et al., 2009). Moreover, sea cucumbers also have impressive amounts of lectins (Gowda et al., 2008), glycosaminoglycans (Wu et al., 2010), omega-6 sterols and omega- 6 and omega- 3 fatty acids (EPA and DHA) and sterols (Fredalina et al., 1999; Zhong et al., 2007). Two compounds were not obtained from the extraction of acetone solvent and hexane which was Lanost-8-en-3ol, (3.beta.) and Farnesene epoxide. Lanost-8-en-3-ol, (3.beta.) or Dihydrolanosterol is compounds contained in plant extract of Dangyuja (Citrus grandis Leaves), which serves as an anticancer. Works well in treating human gastric cancer which malignant (cancer) cells form in the lining of the stomach (Moon et al., 2009). Farnesene epoxide is a compound contained in the extracts of plant Artimisia Herbs-Alba which is widely acquired in the Mediterranean in North Africa, Western Asia and Southwest Europe. People in the region use this plant as an antiseptic and antispasmodic in herbal medicine. In research (Tilaoui et al., 2011), that the compound content of Farnesene epoxide serves as an antiproliferative activity is the ability of a compound to stop the growth of cells and not allowing the cells to multiply rapidly.

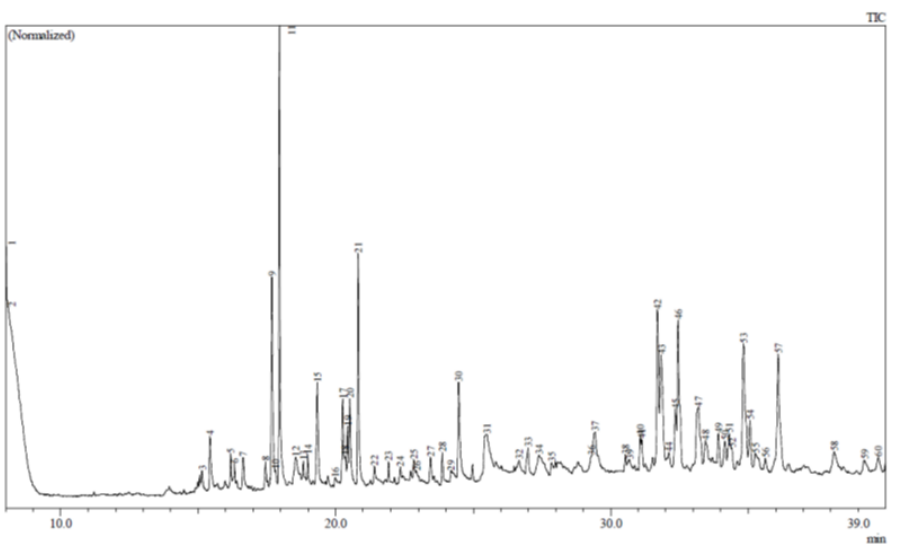

Figure 3. Gas chromatography-mass spectrometry profile for the methanol extract of sea cucumber

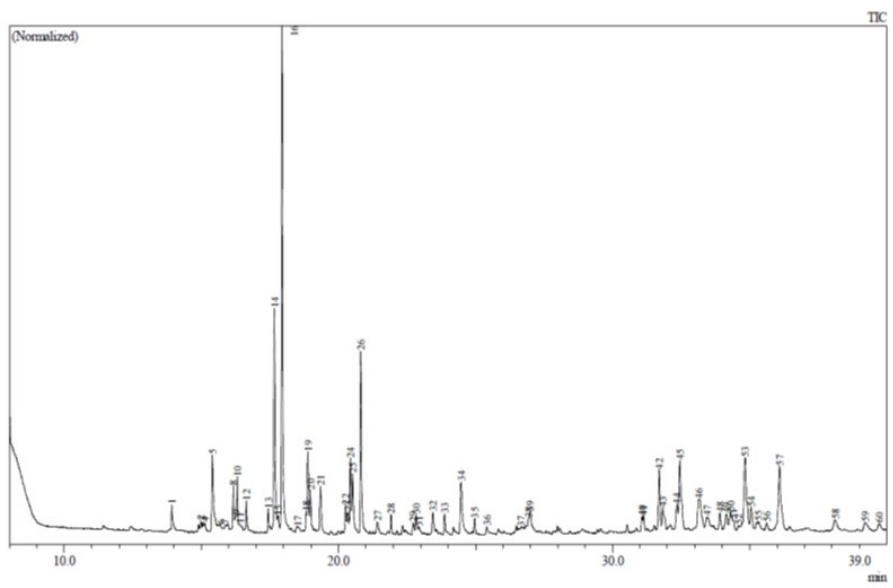

Figure 4. Gas chromatography-mass spectrometry profile for the acetone extract of sea cucumber

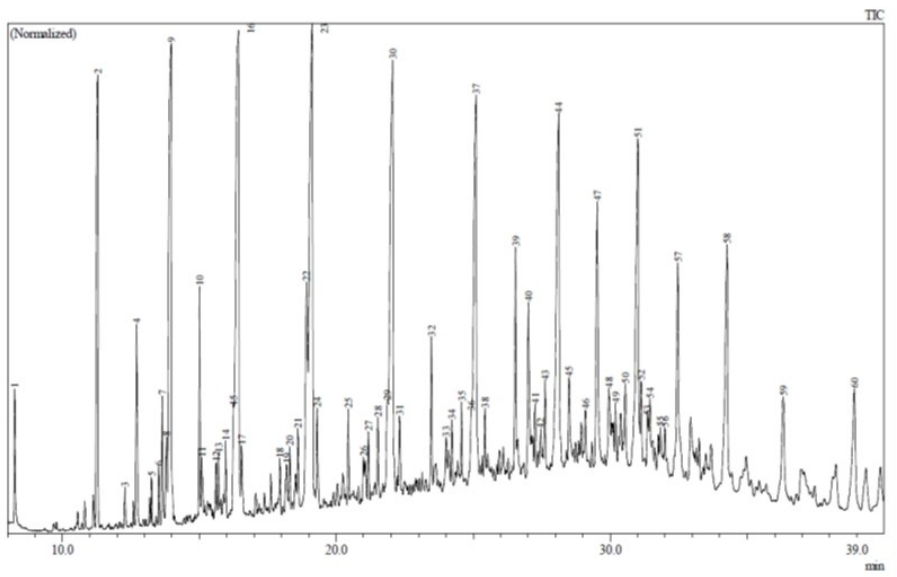

Figure 5. Gas chromatography-mass spectrometry profile for the hexane extract of sea cucumber 
Table 1. GC-MS analysis for the methanol, acetone and hexane extract of sea cucumber

\begin{tabular}{ccccc}
$\begin{array}{c}\text { Antibacterial } \\
\text { Compound }\end{array}$ & $\begin{array}{c}\text { Molecular } \\
\text { formula }\end{array}$ & $\begin{array}{c}\text { Methanol } \\
\text { extract } \\
(\% \text { of Area })\end{array}$ & $\begin{array}{c}\text { Acetone } \\
\text { extract } \\
(\% \text { of Area })\end{array}$ & $\begin{array}{c}\text { Hexane } \\
\text { extract } \\
(\% \text { of Area })\end{array}$ \\
\hline
\end{tabular}

Anti-inflammatory, Antioxidant,

9-Hexadecenoic

acid, methyl $\quad \mathrm{C}_{17} \mathrm{H}_{32} \mathrm{O}_{2} \quad 5.19$

8.19

Hypocholesterolemic nematicide, pesticide, anti-

ester, $(Z)$

- $\quad$ androgenic flavour, hemolytic, 5-Alpha reductase

Hexadecanoic

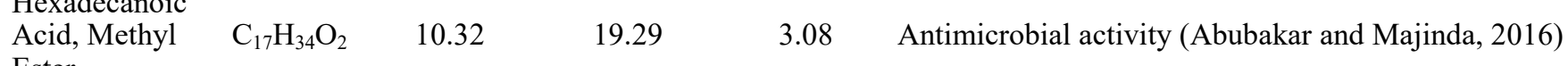

Ester

Tetradecanoic

Acid, Methyl

Ester

$\mathrm{C}_{15} \mathrm{H}_{30} \mathrm{O}_{2} \quad 1.75$

$1.75 \quad 4.41$

1.45

Larvicidal and repellent activity (Abubakar and Majinda, 2016)

inhibitor, potent mosquito larvicide, and antimicrobial activity (Abubakar and Majinda, 2016)

$\begin{array}{ccccc} & & & & \begin{array}{l}\text { Anti-inflammatory, nematicide, pesticide, lubricant, } \\ \text { antiandrogenic, flavour, hemolytic 5-alpha reductase }\end{array} \\ \text { inhibitor, antioxidant, hypocholesterolemic (Anwar } \text { et al., } & \text { 2007) }\end{array}$

9-Octadecenoic

acid (Z) -,

methyl ester

(stearic acid

methyl ester)
$\mathrm{C}_{19} \mathrm{H}_{36} \mathrm{O}_{2} \quad 4.1$

$4.11 \quad 7.51$

Anti-inflammatory, antiandrogenic, cancer preventive, dermatitigenic, irritant, antileukotriene-D4, hypocholesterolemic, 5-alpha reductase inhibitor, anemiagenic, insectifuge, flavor (Abubakar and Majinda, 2016)

\begin{tabular}{llllll}
\hline Tetratriacontane & $\mathrm{C}_{44} \mathrm{H}_{90}$ & 0.95 & - & 29.95 & $\begin{array}{l}\text { Antibacterial and antifungal (M. Abubakar and Majinda, } \\
\text { 2016) }\end{array}$ \\
\hline Pentacosane & $\mathrm{C}_{25} \mathrm{H}_{52}$ & 0.32 & 0.92 & 3.52 & $\begin{array}{l}\text { Antitumor, antimicrobial activity, antivirus (Abubakar and } \\
\text { Majinda, 2016) }\end{array}$ \\
\hline
\end{tabular}

$5,8,11,14-$

Eicosatetraenoi

c Acid, Methyl

Ester, (ALL-Z)

EPA/Omega 3
Preventing and managing heart disease, lower blood pressure, reduce triglycerides accumulation, slow the development of plaque in the arteries, reduce the chance of abnormal heart rhythm, reduce the likelihood of heart attack and stroke, antiinflammatory complications after surgery (Yi et al., 2014)

\begin{tabular}{|c|c|c|c|c|c|}
\hline $\begin{array}{l}=-214-. \text { Beta.-H- } \\
\text { Pregna } 7890-\end{array}$ & $\mathrm{C}_{21} \mathrm{H}_{36}$ & 0.69 & 1.49 & - & Antibacterial and antifungal effects (Dehpour et $a$ \\
\hline $\begin{array}{l}\text { 2- } \\
\text { [(Hexadecyloxy } \\
\text { )Methyl] } \\
\text { Oxirane }\end{array}$ & $\mathrm{C}_{19} \mathrm{H}_{38} \mathrm{O}_{2}$ & 3.36 & 0.73 & - & Antibacterial activity (Henry Wright et al., 2016) \\
\hline
\end{tabular}

Stigmasta-5,22-

dien-3-ol,

$\mathrm{C}_{31} \mathrm{H}_{50} \mathrm{O} \quad 8.18$

Free radical Scavenging, Anti-diabetic, Anticancer

acetate

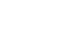

3.96

1.62

(3.beta.)

\begin{tabular}{|c|c|c|c|c|c|}
\hline $\begin{array}{l}\text { Cholest-5-EN-3 } \\
\text {-YL Acetate }\end{array}$ & $\mathrm{C}_{29} \mathrm{H}_{48} \mathrm{O}_{2}$ & 12.06 & 10.82 & - & $\begin{array}{l}\text { Antioxidant activity and antimicrobial activity (Singh et } \\
\text { al., 2020) }\end{array}$ \\
\hline
\end{tabular}

Ergosta-14,22-

Dien-3-OL,
Acetate,
$\mathrm{C}_{30} \mathrm{H}_{50} \mathrm{O}_{2}$
8.18
5.46
Antibacterial activity (Putra and Hadi, 2017)
(3.Beta.,5.Alph
a.,22E)-

Stigmast-5-EN-

3-OL,

(3.Beta.,24S)- / $\quad \mathrm{C}_{29} \mathrm{H}_{50} \mathrm{O} \quad 7.56$

gamma.-

Sitosterol

Thyroid inhibitory, antiperoxidative and hypoglycemic effects (Abubakar and Majinda, 2016) 
Table 1 (Cont.). GC-MS analysis for the methanol, acetone and hexane extract of sea cucumber

\begin{tabular}{lccccc}
\hline $\begin{array}{c}\text { Antibacterial } \\
\text { Compound }\end{array}$ & $\begin{array}{c}\text { Molecular } \\
\text { formula }\end{array}$ & $\begin{array}{c}\text { Methanol } \\
\text { extract } \\
\text { (\% of Area) }\end{array}$ & $\begin{array}{c}\text { Acetone } \\
\text { extract } \\
\text { (\% of Area) }\end{array}$ & $\begin{array}{c}\text { Hexane } \\
\text { extract } \\
(\% \text { of Area })\end{array}$ & Reported bioactivity \\
\hline $\begin{array}{l}\text { Octadecanoic } \\
\text { acid, methyl } \\
\text { ester }\end{array}$ & $\mathrm{C}_{19} \mathrm{H}_{38} \mathrm{O}_{2}$ & 8.49 & 6.64 & 27.03 & Antimicrobial activity (Abubakar and Majinda, 2016) \\
\hline Caryophyllene & $\mathrm{C}_{15} \mathrm{H}_{24}$ & - & - & - & $\begin{array}{l}\text { Anti-inflammatory and Antimicrobial activity } \\
\text { (Manjamalai et al., 2012) }\end{array}$ \\
\hline
\end{tabular}

Azulene,

$1,2,3,5,6,7,8,8 \mathrm{a}-$

octahydro-1,4-

dimethyl-7-(1-

methylethenyl)-

$\mathrm{C}_{15} \mathrm{H}_{24}$

Analgesic, antiasthamatic, anti-inflammatory and

, [1S-

(1.alpha.,7.al)

antipyretic properties (Hameed et al., 2015)

\begin{tabular}{llllll}
\hline Heneicosane & $\mathrm{C}_{21} \mathrm{H}_{44}$ & 0.48 & 0.31 & 3.3 & Anticancer (Ávila et al., 2019) \\
\hline Docosane & $\mathrm{C}_{22} \mathrm{H}_{46}$ & 0.34 & 1.25 & 0.8 & Anti-inflammatory and anti-atherogenic (Uraku, 2016) \\
\hline $\begin{array}{l}\text { Lanost-8-en-3- } \\
\text { ol, (3.beta.) }\end{array}$ & $\mathrm{C}_{30} \mathrm{H}_{52} \mathrm{O}$ & 1.47 & - & - & Anticancer (Moon et al., 2009) \\
$\begin{array}{l}\text { Farnesene } \\
\text { epoxide }\end{array}$ & $\mathrm{C}_{15} \mathrm{H}_{24} \mathrm{O}$ & 0.35 & - & - & Antiproliferative activity (Tilaoui et al., 2011) \\
\hline
\end{tabular}

Chromatogram GC-MS analysis of the acetones extract of sea cucumber showed the presence of sixty major peaks and the components corresponding to the peaks were determined. Major component of this extract are as follows Hexadecanoic Acid, Methyl Ester (19.29\%), Cholest-5-EN-3-YL Acetate (10.82\%), 9Hexadecenoic acid, methyl ester, (Z) (8.3\%), 9Octadecenoic acid (Z) -, methyl ester (stearic acid methyl ester) (7.51\%), Stigmasta-5,22-dien-3-ol, acetate, (3.beta.) $(7.29 \%)$, Octadecanoic acid, methyl ester (6.64\%), and Ergosta-14,22-Dien-3-OL, Acetate, (3.Beta.,5.Alpha.,22E)-(5.46\%), which is an antioxidant and antibacterial component.

GC-MS test performed showed the presence of sixty peaks and components in the hexane extract of sea cucumber. Only eight main components are important as pharmacological material, namely Tetratriacontane (29.95\%), Octadecanoic acid, methyl ester (27.03\%), Pentacosane (3.52\%), Heneicosane (3.3\%), Hexadecanoic Acid, Methyl Ester (3.08\%), Tetradecanoic Acid, Methyl Ester (1.45\%), 5,8,11,14Eicosatetraenoic Acid, Methyl Ester, (ALL-Z) EPA/ Omega $3(1.62 \%)$ and Docosane $(0.80 \%)$. There are two very interesting compounds to be examined and not found by the other two solvents (methanol and acetone) namely Heneicosane that serves as anticancer and Docosane as anti-inflammatory and anti-atherogenic. Research Ávila et al. (2019) find new antiproliferative polyunsaturated epoxy-heneicosane in isolated from the brown alga Lobophora variegata from the Brazilian coastal. Heneicosane is an antiproliferative, its better inhibition of the tumour cell lines in comparison to the fibroblast cell line. Similarities with, eicosapentaenoic acid (EPA) or 5,8,11,14-eicosatetraenoic acid, methyl ester, (ALL-Z) EPA/omega-3 find in sea cucumber Muellaria lacenora, DHA and n-3 polyunsaturated fatty acids (PUFAs) (Abedi and Sahari, 2014). These molecules display antitumor activity through induction of apoptosis in human cancer cells alone or combined with conventional chemotherapeutic agents, for example, n-3 PUFAs may increase tumour cells sensitivity to conventional therapies (Lee et al., 2008; Murray et al., 2015; Zhou et al., 2017). Microdilution method of Heneicosane compounds as antibacterial activity against Staphylococcus aureus and Escherichia coli did not give good results (Ávila et al., 2019).

\subsection{Antibacterial activity}

Antibacterial is a compound that can suppress growth and development of bacterial growth by using bioactive compounds found in sea cucumber, which are generally flavonoids and steroids. Disc diffusion method was followed to determine the antimicrobial activity. Antimicrobial activities of sea cucumber (Muellaria lecanora) extracts were evaluated against three bacterial (two gram-positive, one gram-negative) strains as shown in Table 2 and Figure 6.

The concentration of the acetone, hexane and methanol extract of sea cucumber leaves was calculated as $20 \mu \mathrm{L}$, were screened for sensitivity against the three solvents extract. Initial screening of sea cucumber for antibacterial activity on bacterial strains Escherichia coli Salmonella and Staphylococcus aureus was carried out 
Table 2. Effect of acetone, hexane and methanol extract of sea cucumber against different bacteria pathogens

\begin{tabular}{lccccc}
\hline \multirow{2}{*}{ Samples } & Maceration & \multirow{2}{*}{ Extraction time (hrs) } & Concentration & \multicolumn{3}{c}{ Zone of inhibition (mm) } \\
\cline { 4 - 6 } & & & Escherichia coli & Salmonella & Staphylococcus aureus \\
\hline Methanol extract & & 6.2 & 7.34 & 7.02 \\
Acetone extract & \multirow{2}{*}{$20 \mu \mathrm{L}$} & 6.22 & 7.26 & 6.88 \\
Hexane extract & & 6.84 & 7.87 & 7.22 \\
Control positive & & 12.67 & 25.33 & 21.87 \\
Control negative & & 0 & 0 & 0 \\
\hline
\end{tabular}
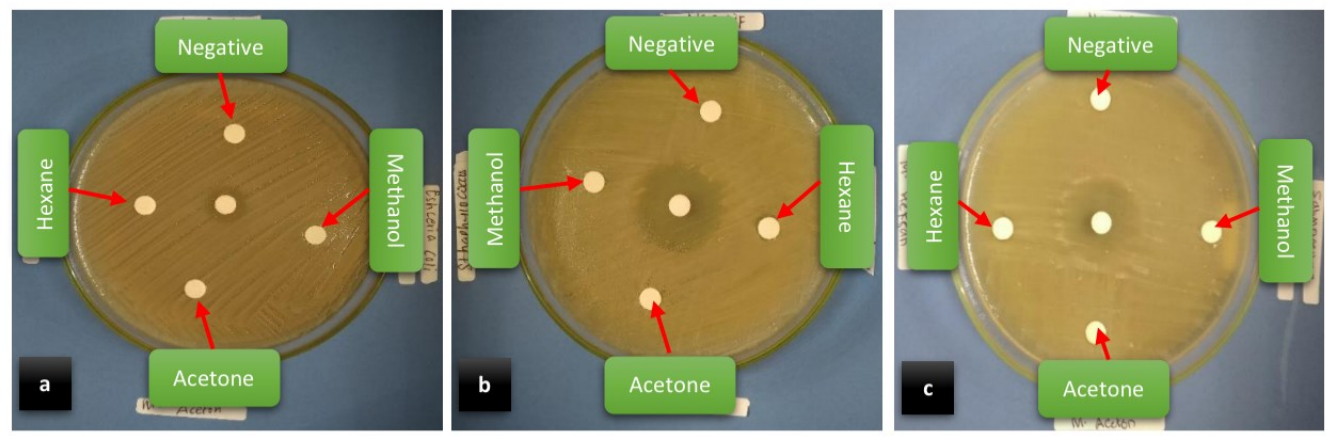

Figure 6. Antibacterial activity against a) Escherichia coli, b) Staphylococcus aureus, and c) Salmonella

via Kirby-Bauer disc diffusion assay. The antibacterial activity was classified as highly active $(>10 \mathrm{~mm})$, mild active $(7-10 \mathrm{~mm})$ and slightly active $(6-7 \mathrm{~mm})$ and less than $6 \mathrm{~mm}$ was taken as inactive (Chandra et al., 2011).

An antibacterial activity can be known by the formation of a bright zone around the disc paper and the bright zone is the inhibitory zone. Methanol extraction exhibited a broad-spectrum antibacterial activity with a minimum zone diameter of $6.20 \mathrm{~mm}$ against bacteria Escherichia coli and hexane extraction a maximum zone diameter of $7.87 \mathrm{~mm}$ against bacteria Salmonella. Methanol extraction belongs to the antibacterial activity slightly active category with an average inhibitory zone of 6-7 mm bacteria Escherichia coli and mild active category with an average inhibitory zone of 7-10 mm against bacteria Salmonella and Staphylococcus aureus (Figure 6). The activity of flavonoids inhibits the growth of bacteria by damaging the cell membrane, thereby inhibiting the synthesis of bacterial cell macromolecules (Dzoyem et al., 2013). The mechanism of the steroid works as an antibacterial by damaging the lipid membrane, so that liposomes leak. Steroids are also known to be interacting with membrane phospholipids, since their permeable nature to lipolytic compounds leads to decreased membrane integrity and morphology of impaired cells membranes, resulting in lysis and fragile cells (Madduluri et al., 2013). The preliminary antibacterial assay of the extracts showed different responses to the test strains with the best activity observed for acetone, methanol and n-hexane extracts of sea cucumber against bacteria gram-positive (Salmonella and Staphylococcus aureus), but not recommended for gram-negative bacteria such as Escherichia coli.

\section{Conclusion}

In summary, acetone and methanol were found to be the best solvent for phytochemicals extraction from Sea cucumber. The methanol and hexane extract showed a maximum number of bioactive compounds in preliminary phytochemical analysis and a good amount of antibacterial activity and total phenolics in the antioxidant activity. Special for methanol extract showed a bioactive compound as an anticancer and antiproliferative activity Lanost-8-en-3-ol, (3.beta.) and Farnesene epoxide. Both of these compounds work well in treating human gastric cancer which malignant cells and ability to stop the growth of cells and not allowing the cells to multiply rapidly. Antibacterial assay results from sea cucumber extract were very effective against bacteria gram-positive (Salmonella and Staphylococcus aureus). The bioautography analysis showed that the whole extract had free radical scavenging and antibacterial potential. GC-MS analysis revealed the presence of a good number of bioactive metabolites such as flavanoid and steroids in the extract. The results of this study implied that sea cucumber genus Muelleria lecanora have shown better antibacterial and antioxidant activities which could be used in the food and therapeutic applications.

\section{References}

Abedi, E. and Sahari, M.A. (2014). Long-chain polyunsaturated fatty acid sources and evaluation of their nutritional and functional properties. Food Science and Nutrition, 2(5), 443-46. https:// doi.org/10.1002/fsn3.121

Abubakar, L., Mwangi, C., Uku, J. and Ndirangu, S. (2012). Antimicrobial activity of various extracts of 
the sea urchin Tripneustes gratilla (Echinoidea). African Journal of Pharmacology and Therapeutics, $1(1), 19-23$.

Abubakar, M. and Majinda, R. (2016). GC-MS Analysis and Preliminary Antimicrobial Activity of Albizia adianthifolia (Schumach) and Pterocarpus angolensis (DC). Medicines, 3(3), 1-9. https:// doi.org/10.3390/medicines3010003

Althunibat, O.Y., Hashim, R., Bakhtiar, M.T., Mohd Daud, J., Ikeda, M.A. and Zali, B.I. (2009). In vitro antioxidant and antiproliferative activities of three Malaysian sea cucumber species. European Journal of Scientific Research, 37(3), 376-387.

Aminin, D.L., Chaykina, E.L., Agafonova, I.G., Avilov, S.A., Kalinin, V.I. and Stonik, V.A. (2010). Antitumor activity of the immunomodulatory lead Cumaside. International Immunopharmacology, 10 (6), 648-654. https://doi.org/10.1016/ j.intimp.2010.03.003

Anwar, F., Latif, S., Ashraf, M. and Gilani, A.H. (2007). Moringa oleifera: A food plant with multiple medicinal uses. Phytotherapy Research, 21(1), 1725. https://doi.org/10.1002/ptr.2023

Ávila, F.N., Pinto, F.C.L., Carneiro, P.B.M., Ferreira, K.Q., Wilke, D.V., Nogueira, N.A.P., Silveira, E.R. and Pessoa, O.D.L. (2019). New antiproliferative polyunsaturated epoxy-heneicosane derivatives isolated from the brown alga lobophora variegata. Journal of the Brazilian Chemical Society, 3(2), 406 -412. https://doi.org/10.21577/0103-5053.20180190

Beauregard, K.A., Truong, N.T., Zhang, H., Lin, W. and Beck, G. (2001). The detection and isolation of a novel antimicrobial peptide from the echinoderm, Cucumaria frondosa. In Beck, G>, Sugumaran, M. and Cooper, E.L. (Eds.) Phylogenetic Perspectives on the Vertebrate Immune System. Advances in Experimental Medicine and Biology. Vol. 484, p. 55 -62. Boston, Massachusetts, USA: Springer. https:// doi.org/10.1007/978-1-4615-1291-2_5

Borsig, L., Wang, L., Cavalcante, M.C.M., Cardilo-Reis, L., Ferreira, P.L., Mourão, P.A.S., Esko, J.D. and Pavão, M.S.G. (2007). Selectin blocking activity of a fucosylated chondroitin sulfate glycosaminoglycan from sea cucumber: Effect on tumor metastasis and neutrophil recruitment. Journal of Biological Chemistry, 282(20), 14984-14991. https:// doi.org/10.1074/jbc.M610560200

Chandra, R., Dwivedi, V., Shivam, K. and Jha, A.K. (2011). Detection of antimicrobial activity of Oscimum sanctum (Tulsi) and Trigonella foenum graecum (Methi) against some selected bacterial and fungal strains. Research Journal of Pharmaceutical, Biological and Chemical Sciences, 2(4), 809-813.
Chen, J. (2004). Present status and prospects of sea cucumber industry in China. In Lovatelli, A., Conand, C., Purcell, S., Uthicke, S., Hamel, J.-F. and Mercier, A. (Eds.) Advances in sea cucumber aquaculture and management. FAO Fisheries Technical Paper 463. Rome: FAO.

Chen, S., Xue, C., Yin, L., Tang, Q., Yu, G. and Chai, W. (2011). Comparison of structures and anticoagulant activities of fucosylated chondroitin sulfates from different sea cucumbers. Carbohydrate Polymers, 83(2), 688-696. https://doi.org/10.1016/ j.carbpol.2010.08.040

Dehpour, A.A., Yousefian, M., Jafary Kelarijani, S.A., Koshmoo, M., Mirzanegad, S., Mahdavi, V., Mousavi, S.E., Shirzad, E., Afzali, M., Javad Bayani, M.J., Olyaei Juybari, E. and Yahyapor, M.K. (2012). Antibacterial activity and composition of essential oils of flower Allium rotundum. Advances in Environmental Biology, 6(3), 1020-1025.

Dzoyem, J.P., Hamamoto, H., Ngameni, B., Ngadjui, B.T. and Sekimizu, K. (2013). Antimicrobial Action Mechanism of Flavonoids from Dorstenia Species. Drug Discoveries and Therapeutics, 7(2), 66-72. https://doi.org/10.5582/ddt.2013.v7.2.66

Fredalina, B.D., Ridzwan, B.H., Abidin, A. A. Z., Kaswandi, M. A., Zaiton, H., Zali, I., Kittakoop, P. and Jais, A. M. M. (1999). Fatty acid compositions in local sea cucumber, Stichopus chloronotus, for wound healing. General Pharmacology, 33(4), 337340. https://doi.org/10.1016/S0306-3623(98)00253-5

Ghanbari, R., Ebrahimpour, A., Abdul-Hamid, A., Ismail, A. and Saari, N. (2012). Actinopyga lecanora hydrolysates as natural antibacterial agents. International Journal of Molecular Sciences, 13(12), 16796-16811. https://doi.org/10.3390/ ijms 131216796

Gowda, N.M., Goswami, U. and Khan, M.I. (2008). Purification and characterization of a $\mathrm{T}$-antigen specific lectin from the coelomic fluid of a marine invertebrate, sea cucumber (Holothuria scabra). Fish and Shellfish Immunology, 24(4), 450-458. https:// doi.org/10.1016/j.fsi.2008.01.002

Hameed, I.H., Hussein, H.J., Kareem, M.A. and Hamad, N.S. (2015). Identification of five newly described bioactive chemical compounds in Methanolic extract of Mentha viridis by using gas chromatography mass spectrometry (GC-MS). Journal of Pharmacognosy and Phytotherapy, 7(7), 107-125. https://doi.org/10.5897/JPP2015.0349

Han, H., Yi, Y. H., Li, L., Liu, B. S., Pan, M. X., Yan, B. and Wang, X.H. (2009). Triterpene glycosides from sea cucumber Holothuria leucospilota. Chinese Journal of Natural Medicines, 7(5), 346-350. https:// 
doi.org/10.3724/SP.J.1009.2009.00346

Henry Wright, M., Jean Arnold, M.S., Aldosary, H., Sirdaarta, J., Carlson Greene, A. and Edwin Cock, I. (2016). Bioactive constituents of Terminalia ferdinandiana Exell: A pharmacognistic approach towards the prevention and treatment of yersiniosis. Pharmacognosy Communications, 6(3), 152-163. https://doi.org/10.5530/pc.2016.3.5

Hing, H., Ambia, K.M., Azraul-Mumtazah, R., Hamidah, S., Sahalan, A., Shamsudin, N., Shamsudin, M. and Hashim, R. (2007). Effect of Methanol Extracts from Sea Cucumbers Holothuria edulis and Stichopus chloronotus on Candida albicans. Microscopy and Microanalysis, 17(2), 270-271. https:// doi.org/10.1017/s1431927607071553

Janakiram, N.B., Mohammed, A. and Rao, C.V. (2015). Sea cucumbers metabolites as potent anti-cancer agents. Marine Drugs, 13(5), 2909-2923. https:// doi.org/10.3390/md13052909

Jiang, J., Zhou, Z., Dong, Y., Cong, C., Guan, X., Wang, B., Chen, Z., Jiang, B., Yang, A., Gao, S. and Sun, H. (2014). Invitro antibacterial analysis of phenoloxidase reaction products from the sea cucumber Apostichopus japonicus. Fish and Shellfish Immunology, 39(2), 458-463. https:// doi.org/10.1016/j.fsi.2014.06.002

Kariya, Y., Watabe, S., Hashimoto, K. and Yoshida, K. (1990). Occurrence of chondroitin sulfate $E$ in glycosaminoglycan isolated from the body wall of sea cucumber Stichopus japonicus. Journal of Biological Chemistry, 265(9), 5081-5085.

Keagle, M.B. and Gersen, S.L. (2005). Basic laboratory procedures. In Gersen, S.L. and Keagel, M.B. (Eds.) The Principles of Clinical Cytogenetics, p. 63-79. Totowa, New Jersey, USA: Humana Press. https:// doi.org/10.1385/1-59259-833-1:063

Kerr, R.G. and Chen, Z. (1995). In vivo and in vitro biosynthesis of saponins in sea cucumbers. Journal of Natural Products, 58(2), 172-176. https:// doi.org/10.1021/np50116a002

Lee, E.S., Son, D.S., Kim, S.H., Lee, J., Jo, J., Han, J., Kim, H., Hyun, J.L., Hye, Y.C., Jung, Y., Park, M., Yu, S.L., Kim, K., Young, M.S., Byung, C.K., Lee, K., Huh, N., Ko, C., Park, K. and Kim, J. (2008). Prediction of recurrence-free survival in postoperative non-small cell lung cancer patients by using an integrated model of clinical information and gene expression. Clinical Cancer Research, 14(22), 7397-7404. https://doi.org/10.1158/1078-0432.CCR07-4937

Li, C., Haug, T., Styrvold, O.B., Jørgensen, T.O. and Stensvåg, K. (2008). Strongylocins, novel antimicrobial peptides from the green sea urchin, Strongylocentrotus droebachiensis. Developmental and Comparative Immunology, 32(12), 1430-1440. https://doi.org/10.1016/j.dci.2008.06.013

Luo, L., Wu, M., Xu, L., Lian, W., Xiang, J., Lu, F., Gao, N., Xiao, C., Wang, S. and Zhao, J. (2013). Comparison of physicochemical characteristics and anticoagulant activities of polysaccharides from three sea cucumbers. Marine Drugs, 11(2), 399-417. https://doi.org/10.3390/md11020399

Madduluri, S., Babu Rao, K. and Sitaram, B. (2013). In vitro evaluation of antibacterial activity of five indigenous plants extract against five bacterial pathogens of human. International Journal of Pharmacy and Pharmaceutical Sciences, 16(32), 16. https://doi.org/10.1186/s12906-016-1007-

Mamelona, J., Pelletier, É., Girard-Lalancette, K., Legault, J., Karboune, S. and Kermasha, S. (2007). Quantification of phenolic contents and antioxidant capacity of Atlantic sea cucumber, Cucumaria frondosa. Food Chemistry, 104(3), 1040-1047. https://doi.org/10.1016/j.foodchem.2007.01.016

Manjamalai, A., Alexander, T. and Berlin Grace, V.M. (2012). Bioactive evaluation of the essential oil of plectranthus amboinicus by GC-MS analysis and its role as a drug for microbial infections and inflammation. International Journal of Pharmacy and Pharmaceutical Sciences, 4(3), 205-211.

Miyamoto, T., Togawa, K., Higuchi, R., Komori, T. and Sasaki, T. (1990). Constituents of Holothuroidea, II. Six newly identified biologically active triterpenoid glycoside sulfates from the sea cucumber Cucumaria echinata. Liebigs Annalen Der Chemie, 1990(5), 453 -460. https://doi.org/10.1002/jlac.199019900186

Mojica, E.-R.E. and Merca, F.E. (2004). Lectin from the Body Walls of Black Sea Cucumber (Holothuria atra Jaeger). Philippine Journal of Science, 133(2), 77-85.

Mojica, E.-R.E. and Merca, F.E. (2005). Biological Properties of Lectin from Sea Cucumber (Holothuria scabra Jaeger). Journal of Biological Sciences, 5(4), 472-477. https://doi.org/10.3923/jbs.2005.472.477

Moon, J.Y., Kim, H., Cho, M., Chang, W.Y., Kim, C.T. and Cho, S.K. (2009). Induction of apoptosis in SNU -16 human gastric cancer cells by the chloroform fraction of an extract of Dangyuja (Citrus grandis) leaves. Journal of Applied Biological Chemistry, 52, 168-175. https://doi.org/10.3839/jksabc.2009.031

Mourão, P.A.S., Guimarães, M.A.M., Mulloy, B., Thomas, S. and Gray, E. (1998). Antithrombotic activity of a fucosylated chondroitin sulphate from echinoderm: Sulphated fucose branches on the 
polysaccharide account for its antithrombotic action. British Journal of Haematology, 101(4), 647-652. https://doi.org/10.1046/j.1365-2141.1998.00769.x

Murray, M., Hraiki, A., Bebawy, M., Pazderka, C. and Rawling, T. (2015). Anti-tumor activities of lipids and lipid analogues and their development as potential anticancer drugs. Pharmacology and Therapeutics, 150, 109-128. https://doi.org/10.1016/ j.pharmthera.2015.01.008

Nagase, H., Enjyoji, K.I., Minamiguchi, K., Kitazato, K.T., Kitazato, K., Saito, H. and Kato, H. (1995). Depolymerized holothurian glycosaminoglycan with novel anticoagulant actions: Antithrombin III- and heparin cofactor II-independent inhibition of factor $\mathrm{X}$ activation by factor IXa-factor VIIIa complex and heparin cofactor II-dependent inhibition of thromb. Blood, 85(6), 1527-1534. https://doi.org/10.1182/ blood.v85.6.1527.bloodjournal8561527

Nguyen, T.H., Um, B.H. and Kim, S.M. (2011). Two Unsaturated Fatty Acids with Potent $\alpha$-Glucosidase Inhibitory Activity Purified from the Body Wall of Sea Cucumber (Stichopus japonicus). Journal of Food Science, 76(9), 208-214. https:// doi.org/10.1111/j.1750-3841.2011.02391.x

Olivera-Castillo, L., Grant, G., Kantún-Moreno, N., Acevedo-Fernández, J. J., Puc-Sosa, M., Montero, J., Olvera-Novoa, M.A., Negrete-León, E., SantaOlalla, J., Ceballos-Zapata, J., Bercansil, M.C.M., Merca, F.E., Lindsay-Edwards, J., Puerto-Castillo, C., Gil-Zamorano, J., Fernández-Herrera, M.A., Pérez-Tapia, M., Dávalos, A. and Rodriguez-Canul, R. (2018). Sea cucumber (Isostichopus badionotus) body-wall preparations exert anti-inflammatory activity in vivo. PharmaNutrition, 6(2), 74-80. https://doi.org/10.1016/j.phanu.2018.03.002

Pacheco, R.G., Vicente, C.P., Zancan, P. and Mourão, P.A.S. (2000). Different antithrombotic mechanisms among glycosaminoglycans revealed with a new fucosylated chondroitin sulfate from an echinoderm. Blood Coagulation and Fibrinolysis, 11(6), 563573. https://doi.org/10.1097/00001721-20000900000009

Pangestuti, R. and Arifin, Z. (2018). Medicinal and health benefit effects of functional sea cucumbers. Journal of Traditional and Complementary Medicine, 8(3), 341-351. https://doi.org/10.1016/ j.jtcme.2017.06.007

Putra, M.Y. and Hadi, T.A. (2017). Chemical Composition, Antimicrobial, Cytotoxic and Antiplasmodial Activities of Three Sponges from Buton Islands, Indonesia. Indonesian Journal of Marine Sciences, 22(3), 147-154. https:// doi.org/10.14710/ik.ijms.22.3.147-154
Roginsky, A.B., Ding, X.-Z., Singh, B., Ujiki, M., Salabat, M.R., Chan, C.-Y., Bell, R.H., Collin, P. and Adrian, T.E. (2004). Frondanol-A5 from Cucumaria frondosa induces cell cycle arrest and apoptosis in pancreatic cancer cells. Journal of the American College of Surgeons, 199(3), 91. https:// doi.org/10.1016/j.jamcollsurg.2004.05.198

San Miguel-Ruiz, J.E. and García-Arrarás, J.E. (2007). Common cellular events occur during wound healing and organ regeneration in the sea cucumber Holothuria glaberrima. BMC Developmental Biology, 7(1), 15. https://doi.org/10.1186/1471-213X $-7-115$

Silchenko, A.S., Avilov, S.A., Kalinin, V.I., Kalinovsky, A.I., Dmitrenok, P.S., Fedorov, S.N., Stepanov, V.G., Dong, Z. and Stonik, V.A. (2008). Constituents of the sea cucumber Cucumaria okhotensis. Structures of okhotosides B1-B3 and cytotoxic activities of some glycosides from this species. Journal of Natural Products, 71(3), 351356. https://doi.org/10.1021/np0705413

Singh, A., Palariya, D., Dhami, A., Prakash, O., Kumar, R., Rawat, D.S. and Pant, A.K. (2020). Biological activities and Phytochemical analysis of Zanthoxylum armatum DC. leaves and bark extracts collected from Kumaun region, Uttarakhand, India. Journal of Medicinal Herbs and Ethnomedicine, 6, 5754. https://doi.org/10.25081/jmhe.2020.v6.5754

Sugawara, T., Zaima, N., Yamamoto, A., Sakai, S., Noguchi, R. and Hirata, T. (2006). Isolation of sphingoid bases of sea cucumber cerebrosides and their cytotoxicity against human colon cancer cells. Bioscience, Biotechnology and Biochemistry, 70(12), 2906-2912. https://doi.org/10.1271/bbb.60318

Tian, F., Zhang, X., Tong, Y., Yi, Y., Zhang, S., Li, L., Sun, P., Lin, L. and Ding, J. (2005). PE, a new sulfated saponin from sea cucumber, exhibits antiangiogenic and anti-tumor activities in vitro and in vivo. Cancer Biology and Therapy, 4(8), 874-882. https://doi.org/10.4161/cbt.4.8.1917

Tilaoui, M., Mouse, H.A., Jaafari, A., Aboufatima, R., Chait, A. and Zyad, A. (2011). Chemical composition and antiproliferative activity of essential oil from aerial parts of a medicinal herb Artemisia herba-alba. Brazilian Journal of Pharmacognosy, 21 (4), 781-785. https://doi.org/10.1590/S0102$695 \times 2011005000114$

Tong, Y., Zhang, X., Tian, F., Yi, Y., Xu, Q., Li, L., Tong, L., Lin, L. and Ding, J. (2005). Philinopside A, a novel marine-derived compound possessing dual anti-angiogenic and anti-tumor effects. International Journal of Cancer, 114(6), 843-853. https://doi.org/10.1002/ijc.20804 
Uraku, A.J. (2016). GC/MS determination of bioactive constituents of methanol fraction of Spilanthes uliginosa (SW) leaves. Research Journal of Medicinal Plant, 10(1), 42-54. https:// doi.org/10.3923/rjmp.2016.42.54

Ustyuzhanina, N.E., Bilan, M.I., Dmitrenok, A.S., Shashkov, A.S., Kusaykin, M.I., Stonik, V.A., Nifantiev, N.E. and Usov, A.I. (2016). Structure and biological activity of a fucosylated chondroitin sulfate from the sea cucumber Cucumaria japonica. Glycobiology, 26(5), 449-5. https://doi.org/10.1093/ glycob/cwv119

Wen, J., Hu, C. and Fan, S. (2010). Chemical composition and nutritional quality of sea cucumbers. Journal of the Science of Food and Agriculture, 90(14), 2469-2474. https:// doi.org/10.1002/jsfa.4108

Wu, M., Xu, S., Zhao, J., Kang, H. and Ding, H. (2010). Free-radical depolymerization of glycosaminoglycan from sea cucumber Thelenata ananas by hydrogen peroxide and copper ions. Carbohydrate Polymers, 80(4), 1116-1124. https://doi.org/10.1016/ j.carbpol.2010.01.032

Ye, X., Anjum, K., Song, T., Wang, W., Yu, S., Huang, H., Lian, X.Y. and Zhang, Z. (2016). A new curvularin glycoside and its cytotoxic and antibacterial analogues from marine actinomycete Pseudonocardia sp. HS7. Natural Product Research, 30(10), 1156-1161. https:// doi.org/10.1080/14786419.2015.1047775

Yi, T., Li, S.M., Fan, J.Y., Fan, L.L., Zhang, Z. F., Luo, P., Zhang, X.J., Wang, J.G., Zhu, L., Zhao, Z.Z. and Chen, H.B. (2014). Comparative analysis of EPA and DHA in fish oil nutritional capsules by GC-MS. Lipids in Health and Disease, 13(1), 190. https:// doi.org/10.1186/1476-511X-13-190

Zhao, Y., Li, B., Liu, Z., Dong, S., Zhao, X. and Zeng, M. (2007). Antihypertensive effect and purification of an ACE inhibitory peptide from sea cucumber gelatin hydrolysate. Process Biochemistry, 42(12), 1586-1591. https://doi.org/10.1016/ j.procbio.2007.08.011

Zhong, Y., Khan, M.A. and Shahidi, F. (2007). Compositional characteristics and antioxidant properties of fresh and processed sea cucumber (Cucumaria frondosa). Journal of Agricultural and Food Chemistry, 55(4), 1188-1192. https:// doi.org/10.1021/jf063085h

Zhou, J.K., Zheng, Y.Z., Liu, X.S., Gou, Q., Ma, R., Guo, C.L., Croce, C.M., Liu, L. and Peng, Y. (2017). ROR1 expression as a biomarker for predicting prognosis in patients with colorectal cancer. Oncotarget, 8(20), 32864-32872. https:// doi.org/10.18632/oncotarget.15860

Zhou, X., Wang, C. and Jiang, A. (2012). Antioxidant peptides isolated from sea cucumber Stichopus Japonicus. European Food Research and Technology, 234, 441-447. https://doi.org/10.1007/ s00217-011-1610-x

Zou, Z.R., Yi, Y.H., Wu, H.M., Wu, J.H., Liaw, C.C. and Lee, K.H. (2003). Intercedensides A-C, three new cytotoxic triterpene glycosides from the sea cucumber Mensamaria intercedens Lampert. Journal of Natural Products, 66(8), 1055-1060. https:// doi.org/10.1021/np030064y 